\title{
PENGARUH LATIHAN PLYOMETRIC (SHOOTING) TERHADAP HASIL TINGGI LONCATAN DALAM EKSTRAKURIKULER BOLA VOLI
}

\author{
Ahmad Yani ${ }^{1}$, Restu Gayuh Subekti ${ }^{2}$, Suryadi $^{3}$ \\ ${ }^{1,2}$ Program Studi Pendidikan Jasmani Kesehatan dan Rekreasi, STKIP SITUS Banten, \\ ${ }^{3}$ Program Studi Pendidikan Bahasa Inggris, STKIP SITUS Banten, \\ Jln. Raya Cipocok Kota Serang Banten \\ 1e-mail: ahmad.yani@stkipsitusbanten.ac.id
}

\begin{abstract}
Abstrak
Penelitian ini bertujuan untuk mengetahui pengaruh latihan shooting terhadap hasil tinggi loncatan siswa peserta ekstrakurikuler bola voli di MA Raudlatul Ulum Anyer. Penelitian ini merupakan penelitian eksperimen dengan desain one group pretest and posttest design. Populasi dan sampel dalam penelitian ini adalah 15 siswa. Instrumen penelitian menggunakan vertical jump, dengan reliabilitas sebesar 0.93 dan validitas sebesar 0.78 (Sargent, 1924). Analisis data menggunakan uji t. Hasil penelitian menunjukkan bahwa ada pengaruh latihan shooting terhadap peningkatan tinggi loncatan siswa peserta ekstrakurikuler, dengan t hitung $5.303>\mathrm{t}$ tabel 2.13, Dari data pre-test memiliki rerata $37.53 \mathrm{~cm}$, selanjutnya pada saat posttest rerata mencapai $41.00 \mathrm{~cm}$. Besarnya perubahan tinggi loncatan tersebut dapat dilihat dari perbedaan nilai rata-rata yaitu sebesar $3.47 \mathrm{~cm}$ dan dengan kenaikan presentase sebesar $9.24 \%$. Dari hasil ini dapat disimpulkan latihan shooting berpengaruh untuk meningkatkan tinggi loncatan siswa peserta ekstrakurikuler bola voli di MA Raudlatul Ulum Anyer.
\end{abstract}

Kata kunci: latihan shooting, ekstrakurikuler, tinggi loncatan.

\begin{abstract}
This study aims to determine the effect of shooting training on the jump height of volleyball extracurricular participants in MA Raudlatul Ulum Anyer. This research is an experimental research design with one group pretest and posttest design. The population and sample in this study were 15 students. The research instrument uses vertical jump, this measuring instrument has a reliability of 0.93 with a validity of 0.78 (Sargent, 1924). Data analysis using $t$ test. The results showed that there was an effect of shooting training on the increase in jump height of extracurricular participants, with a t count of 5.303> t table 2.13. The magnitude of the change in jump height can be seen from the difference in the mean value of $3.47 \mathrm{~cm}$ and with a percentage increase of $9.24 \%$. From these results it can be concluded that shooting exercises have an effect on increasing the height of the volleyball extracurricular participants in MA Raudlatul Ulum Anyer.
\end{abstract}

Keywords: shooting training, extracurricular, jump height.

\section{PENDAHULUAN}

Pendidikan memiliki peran yang sangat penting dalam kehidupan manusia. pendidikan menjadi kebutuhan manusia. Menurut Tilaar (2012: 435), hakikat pendidikan adalah memanusiakan manusia, yaitu suatu proses yang melihat manusia sebagai suatu keseluruhan di dalam eksistensinya. Ahmad (2011: 3) 
menjelaskan bahwa: "Tujuan pokok pendidikan adalah membentuk anggota masyarakat menjadi orang-orang yang berpribadi, berperikemanusiaan maupun menjadi anggota masyarakat yang dapat mendidik dirinya sesuai dengan watak masyarakat itu sendiri, mengurangi beberapa kesulitan atau hambatan perkembangan hidupnya dan berusaha untuk memenuhi kebutuhan hidup maupun mengatasi problematikanya."

Salah satu bentuk kegiatan dalam dunia pendidikan adalah kegiatan ekstrakurikuler. Menurut Sumarna Mumuh (2006: 10), kegiatan ekstrakurikuler yang dimaksudkan untuk lebih mengaitkan antara pengetahuan yang diperoleh dalam program kurikulum dengan keadaan dan kebutuhan lingkungan. Nasrudin (2010: 12) mengungkapkan bahwa kegiatan ekstrakurikuler memiliki tujuan sebagaimana dijelaskan berikut ini. Siswa dapat memperdalam dan memeperluas pengetahuan keterampilan mengenai hubungan antara berbagai mata pelajaran, menyalurkan bakat dan minat, serta melengkapi upaya pembinaan manusia seutuhnya yang: a) beriman dan bertakwa kepada Tuhan Yang Maha Esa. b) berbudi pekerti luhur.c) memiliki pengetahuan dan keterampilan. d)Sehat rohani dan jasmani. e)berkepribadian yang mantap dan mandiri. f) memiliki rasa tanggung jawab kemasyarakatan dan kebangsaan.

Kegiatan ekstrakurikuler yang diikuti siswa merupakan kegiatan positif yang pengaruhnya langsung pada siswa dan diharapkan dapat meningkatkan hasil belajar siswa. Dari sekian banyak ekstrakurikuler yang ada di MA Raudlatul Ulum Anyer ternyata ekstrakurikuler bola voli merupakan kegiatan yang sangat digemari. Menurut Rohendi \& Suwandar (2017: 14), permainan bola voli adalah olahraga yang dimainkan oleh dua tim yang masing-masing tiap tim terdiri dari 6 pemain dilapangan, dibatasi dengan ne, tiap tim memiliki tiga kali sentuhan untuk mengembalikan bola yang sama pada tim lawan.

Menurut Subroto, Yunyun \& Yusuf (2016: 24), melalui prermainan bola voli, seluruh potensi diri seluruh aspek tersebut diyakini berpotensi untuk dapat ditumbuh kembangkan. Sampai batas-batas tertentu, seperti misalnya, dengan berlatih dan bermain bola voli secara teratur selain dapat meningkatkan keterampilan bermain bola voli itu sendiri, juga dapat ditingkatkan keterampilan 
fisik, kebugaran jasamani, kemampuan berpkir, keterampilan sosial, bekerjasama, dan mengembangkan sikap positif dan fair play". Dengan demikian banyak sekali manfaat yang bisa didapatkan ketika siswa belajar keterampilan bola voli.

Secara umum diketahui bahwa teknik-teknik dasar dalam permainan bola boli terdiri atas service, passing, block and smash. Menurut Ahmadi (2017: 20), servis yaitu pukulan bola yang dilakukan dari belakang garis akhir lapangan permainan melampaui net ke daerah lawan. Selanjutnya, passing adalah upaya seorang teman dengan menggunakan suatu tehnik tertentu untuk mengoperkan bola yang dimainkannya kepada teman seregunya untuk dimainkan di lapangan sendiri sedangkan spike adalah bentuk serangan yang paling banyak digunakan dalam upaya memperoleh nilai oleh suatu tim, sementara block adalah benteng pertahanan pertama dan paling utama untuk menangkis serangan lawan.

Dari berbagai teknik tersebut ada beberapa tehnik yang membutuhkan loncatan untuk melakukannya, misalkan seperti servis jump, spike, blok bahkan memberi umpan. Dalam perkembangan bola voli saat ini kemampuan meloncat sangatlah penting bagi pemain bola voli karena banyak teknik pada permainan bola voli yang memakai loncatan. Menurut Djumidar (2004: 59), loncat adalah suatu gerakan mengangkat tubuh dari suatu titik ke titik lain yang lebih jauh atau lebih tinggi dengan ancang-ancang lari cepat atau lambat 4 dengan menumpu dua kaki dan mendarat dengan kaki atau anggota tubuh lainnya dengan keseimbangan yang baik. Dikatakan penting karena dalam permainan bola voli banyak teknik yang menggunakan loncatan seperti blok, jump servis dan smash (spike). Menurut Satriya (2014: 62), power adalah kemampuan otot untuk mengerahkan kekuatan maksimal dalam waktu yang sangat cepat. Atau dengan kata lain power adalah kemampuan seseorang untuk melakukan kekuatan maksimal, dengan usaha yang dikerahkan dalam waktu yang sesingkat mungkin. Jika seseorang memiliki kemampuan yang lebih dan dalam waktu yang relatif singkat, berarti memiliki power yang baik.

Bagi para pelatih khususnya di Indonesia sangatlah penting untuk mendesain suatu latihan fisik yang dapat meningkatkan tinggi loncatan, mengingat postur dari pemain bola voli Indonesia lebih kecil dan pendek dibanding pemain 
dari Negara-negara lain di dunia. Menurut Sukadiyanto (2010: 1), menerangkan bahwa pada prinsipnya latihan merupakan suatu proses perubahan ke arah yang lebih baik, yaitu untuk meningkatkan kualitas fisik kemampuan fungsional peralatan tubuh dan kualitas psikis anak latih. Lebih lanjut menurut Sukadiyanto (2010: 5), latihan berasal dari kata dalam bahasa Inggris yang dapat mengandung beberapa makna seperti: practice, excercies, dan training.

Menurut peneliti salah satu latihan yang di gunakan untuk meningkatkan kemampuan kekuatan adalah latihan shooting, karena dengan latihan shooting sangat membantu dalam membina kekuatan kaki, pergelangan kaki, daya tahan, koordinasi gerak, dan membantu meningkatkan kualitas gerak pergelangan tangan. Shooting merupakan gerakan plyometric yang digunkan untuk menggerakkan otot tungkai dan otot-otot khusus (Pertama, 2013: 6). Dalam kegiatan ekstrakurikuler bola voli di MA Raudlatul Ulum Anyer ini sudah terdapat program latihan setiap minggunya akan tetapi masih belum ada latihan yang diprioritaskan untuk meningkatkan daya ledak yang seharusnya dapat meningkatkan tinggi lompatan para peserta didik di ekstrakurikuler bola voli ini. Pelatihan shooting ini juga melibatkan otot-otot gluteus, hamstrings, quadriceps, gastrocnemius, fleksor pinggul, abductor paha, stabilizer lutut, dan ankle, serta melatih beberapa persendian (Furqon dan Doewes, 2002).

Dilihat dari segi permainan yang telah di amati, peneliti mengambil kesimpulan bahwa permainan yang dilakukan peserta didik masih belum dikatakan baik karena tinggi loncatan masih masih kurang. Untuk mencapai prestasi maksimal dalam permainan bola voli diperlukan upaya dan usaha dalam meningkatkan kualitas fisik, teknik, dan mental, upaya dalam neningkatkan teknik dasar seperti servis, passing, smash dan block memerlukan metode yang efisien dan efektif artinya bahwa dalam usaha pengembangan kondisi fisik maka seluruh komponen tersebut harus dikembangkan. Usaha dalam meningkatkan kualitas fisik di perlukan unsur yang mendukung salah satunya seperti daya ledak (power). Dari latar belakang masalah di atas penelitian ini bertujuan untuk mengetahui pengaruh latihan shooting terhadap tinggi loncatan siswa peserta ekstrakurikuler bola voli di MA Raudlatul Ulum Anyer. 
p-ISSN: 2089-2829

e-ISSN: 2407-1528

http://journal.ikippgriptk.ac.id/index.php/olahraga

DOI: 10.31571/jpo.v9i1.1705
Jurnal Pendidikan Olahraga

Vol.9, No.1 Juni 2020

hal 83-92

\section{METODE}

Jenis penelitian ini adalah penelitian eksperimen. Rancangan eksperimen merupakan metode yang memberikan atau menggunakan suatu gejala yang disebut latihan kepada kelompok tertentu dan dengan kondisi-kondisi tertentu yang dapat dikontrol. Menurut Narbuko, (2007: 51), penelitian eksperimen bertujuan untuk menyelidiki kemungkinan saling hubungan sebab akibat dengan cara mengenakan kepada satu atau lebih kelompok eksperimental, satu atau lebih kondisi perlakuan dari membandingkan hasilnya dengan satu atau lebih kelompok kontrol yang tidak dikenai kondisi perlakuan. Desain yang digunakan oleh peneliti adalah menggunakan one group pre-test dan posttest desain, yaitu desain yang terdapat pretest sebelum adanya perlakuan dan post-test setelah diberikan perlakuan. Dalam penelitian ini peneliti ingin mengetahui apakah ada pengaruh latihan shooting terhadap tinggi loncatan peserta ekstrakurikuler bola voli.

Populasi dalam penelitian ini adalah peserta ekstrakurikuler bola voli MA Raudlatul Ulum Anyer berjumlah 15 orang. Oleh karena jumlah populasi kurang dari 100 maka seluruh populasi menjadi sampel peneletian (Sugiyono, 2013). Penelitian ini menggunaan metode one grup pre-test dan post-test dengan tes awal menggunakan tes vertical jump untuk mengetahui tinggi loncatan peserta sebelum mendapatkan treatment dengan latihan shooting. Tata cara melakukan testee berdiri tegak menempel dinding yang sudah ada alat ukur ketinggian dengan satuan centimeter $(\mathrm{cm})$, salah satu tangan lurus ke atas dan testor mencatat tinggi sebelum meloncat, kaki di tekuk $110^{\circ}$ dan loncat setinggi-tingginya dan testor mencatat hasil raihan yang pada nantinya akan di olah datanya, dan setiap peserta mendapat 2 kali kesempatan. Setelah semua melakukan pre-test peneliti memberikan treatment dengan latihan shooting yang dilakukan selama 30 detik setiap tesnya dan dilakukan dengan repetisi 8-10 kali pengulangan. Menurut Arikunto (2002: 136) instrumen penelitian adalah alat atau fasilitas yang digunakan peneliti dalam pengumpulan data agar pekerjaanya lebih mudah dan baik. Data dalam penelitian ini adalah dengan tinggi loncatan. Instrumen tes yang digunakan untuk pengukuran awal (pretest) maupun pengukuran akhir (posttest) menggunakan tes vertical jump (loncat tegak). Instrumen yang digunakan dalam penelitian ini yaitu: (1) dinding, 
(2) papan berukuran 30x150 $\mathrm{cm}^{2}$ atau penggaris kayu yang ada skala ukuran centimeter digantung di dinding dengan ketinggian $150 \mathrm{~cm}$ dari lantai, (3) sebuk kapur, dan (4) penghapus, dan alat pencatat hasil.

Alat ukur untuk mengukur power tungkai adalah dengan menggunakan tes vertical jump. Alat ukur ini mempunyai validitas yang tinggi yaitu sebesar 0,78 dan dengan reliabilitas sebesar 0,93 d (Sargent, 1924). Adapun petunjuk instrumen dalam penelitian ini adalah sebagai berikut (Depdiknas, 2010: 24): (1) Testee berdiri tegak dekat dinding, bertumpu pada kedua kaki, dan papan dinding berada di samping tangan kiri atau tangan kanannya, (2) Tangan yang berada dekat dinding diangkat lurus ke atas telapak tangan, ditempelkan pada papan berskala, sehingga meninggalkan bekas raihan jarinya, (3) Kedua tangan lurus berada di samping telinga, (4) Testee mengambil sikap awalan dengan membengkokan kedua lutut dan kemudian testee meloncat setinggi mungkin sambil menepuk skala dengan tangan terdekat dengan dinding, sehingga meninggalkan bekas raihan pada papan skala, dan (5) Tanda itu menampilkan tinggi rendahnya raihan loncatan testee tersebut. Testee diberi kesempatan melakukan sebanyak tiga kali loncatan.

\section{Tabel 1 Instrumen Penilaian Latihan Shooting}

\begin{tabular}{cll}
\hline $\begin{array}{c}\text { Kompetensi } \\
\text { Dasar }\end{array}$ & \multicolumn{1}{c}{$\begin{array}{c}\text { Indikator } \\
\text { Esensial }\end{array}$} & \multicolumn{2}{c}{ Deskripsi Gerak } \\
\hline $\begin{array}{c}\text { Menganalisis } \\
\text { Gerakan }\end{array}$ & Posisi dan Sikap & Berdiri tegak dengan kedua tangan \\
Shooting & & memegang ujung tali \\
& & Tali di genggam diantara ibu jari dan \\
& & persendian kedua pada jari telunjuk \\
& & Tempatkan tali di belakang tubuh sebagai \\
& & awalan \\
& & Kedua lutut dan pinggul sedikit ditekuk \\
\cline { 2 - 4 } & Pelaksanaan & Lakukan loncatan dengan irama cepat. \\
& Gerakan & Loncatan harus cukup tinggi untuk tempat \\
& & lewatnya tali \\
& & Dilakukan dengan kedua ujung telapak kaki \\
\hline
\end{tabular}




\section{HASIL DAN PEMBAHASAN}

Hasil hasil tinggi loncatan siswa sebelum (pre-test) dan sesudah (postest) diterapkan latihan shooting disajikan dalam Tabel 2.

Tabel 2 Hasil Pretest dan Post-test

\begin{tabular}{ccc}
\hline Statistik & Pre-test & Posttest \\
\hline N & 15 & 15 \\
Rata-rata & 37.53 & 41.00 \\
Nilai Tengah & 40 & 36 \\
Simpangan Baku & 9.891 & 9.907 \\
Nilai Minimal & 20.00 & 25.00 \\
Nilai Maksimal & 60.00 & 61.00 \\
\hline
\end{tabular}

Tabel 3 Hasil Uji-t

\begin{tabular}{ccccc}
\hline Kelas & Rata-rata & t hitung & t tabel & p \\
\hline Pre-test Shooting & 37,53 & 5,303 & 2,131 & 0,000 \\
Posttest Shooting & 41,00 & 5,303 & 2,131 & 0,000 \\
\hline
\end{tabular}

Untuk mengetahui ada tidaknya peningkatan loncatan peserta ekstrakurikuler bola voli dengan latihan shooting, dianalisis menggunakan uji-t atau t-test. Kesimpulan penelitian dinyatakan signifikan apabila nilai t hitung $>\mathrm{t}$ tabel dan pada taraf signifikansi 5\%. Berdasarkan hasil uji-t tersebut diketahui bahwa nilai t hitung sebesar 5.303 dengan taraf signifikansi 5\%. Nilai t tabel dengan $\mathrm{df}=15$ pada taraf signifikansi $5 \%$ adalah 2,131 , karena nilai $\mathrm{t}$ hitung $>\mathrm{t}$ tabel $(5.303>2.131)$, dari data pretest memiliki rerata $37.53 \mathrm{~cm}$, selanjutnya pada saat post-test rerata mencapai $41.00 \mathrm{~cm}$. Besarnya perubahan tinggi loncatan tersebut dapat dilihat dari perbedaan nilai rata-rata yaitu sebesar $3.47 \mathrm{~cm}$, dengan kenaikan presentase $9.24 \%$. Hal ini berarti ada peningkatan loncatan peserta ekstrakurikuler bola voli dengan latihan shooting, sehingga hipotesis pertama dalam penelitian ini diterima.

Penelitian ini bertujuan untuk mengetahui ada tidaknya pengaruh latihan shooting terhadap tinggi loncatan pada peserta ekstrakurikuler bola voli di MA 
Raudlatul Ulum Anyer. Berdasarkan analisis data hasil penelitian diperoleh peningkatan yang signifikan terhadap kelompok yang diteliti. Pemberian perlakuan 16 kali pertemuan dengan frekuensi 4 kali dalam seminggu memberikan pengaruh terhadap peningkatan tinggi loncatan peserta ekstrakurikuler bola voli di MA Raudlatul Ulum Anyer. Latihan dalam penelitian ini menggunakan intensitas maksimal (irama cepat), volume latihan akan meningkat dalam setiap 2 kali pertemuan baik dalam set atau repetisinya sampai pada sesi terakhir (sesi ke-16).

Dengan frekuensi latihan 4 kali seminggu,Sedangkan menurut menu latihan yang benar untuk latihan power mempunyai intensitas sebesar 30\%-60\% dari kekuatan maksimal (1 RM), volume latihan 4set/sesi dengan repetisi 15-20 repetisi/set dengan cara pelaksanaan secepat mungkin dan frekuensi latihan 4 kali seminggu. Sedangkan menurut Sukadiyanto (2010: 192) menu latihan kecepatan yang berguna untuk meningkatkan power tungkai adalah intensitas: maksimal ( kecepatan maksimal), denyut jantung: 185-200x/menit, volume:5-10 repetisi/set, dan 3-5set/sesi, t.kerja: 5-10 detik, t.recovery: 1:6 (denyut jantung 145160x/menit).

Hasil analisis menunjukkan bahwa terdapat peningkatan tinggi loncatan peserta ekstrakurikuler bola voli MA Raudlatul Ulum Anyer sesudah latihan Shooting, hal ini di tunjukan dengan nilai t hitung 5,303 > t table 2.131 maka hasil ini menunjukkan terdapat perbedaan yang signifikan. Dengan demikian hipotesis alternative (Ha) yang berbunyi "Ada pengaruh latihan Shooting terhadap tinggi loncatan perserta ekstrakurikuler bola voli di MA Raudlatul Ulum Anyer", diterima. Artinya latihan shooting memberikan pengaruh yang signifikan terhadap tinggi loncatan para peserta ekstrakurikuler bola voli di MA Raudlatul Ulum Anyer. Besarnya perubahan tinggi loncatan tersebut dilihat dari perbedaan nilai rata-rata yaitu sebesar $3.47 \mathrm{~cm}$, dengan kenaikan presentase $9.24 \%$.

Latihan shooting adalah bentuk latihan plyometric. Untuk melakukan gerakan shooting ini diawali dengan posisi berdiri dengan kedua kaki rapat, kedua lengan berada di samping badan dengan memegang ujung tali shooting, kemudian ayunkan tali shooting melewati kepala sampai kaki dan meloncatinya, lakukan gerakan shooting secepat mungkin, lakukan dengan repetisi 10 dan jumlah set 5 
dan dalam 2 kali pertemuan repetisi maupun set akan meningkat 2 digit untuk repetisi dan 1 digit untuk set dengan irama secepat mungkin (eksplosif), frekuensi: 4x seminggu, recovery: 1menit/set dengan lama latihan 10-30 menit setiap pertemuannya. Plyometric merupakan salah satu model latihan yang sering digunakan untuk para pelatih untuk meningkatkan eksplosif kekuatan (Nur Subekti, 2011: 15). Terkait dengan penggunaan latihan plyometric akan diberikan bentuk gerakan latihan yang variatif untuk mengurangi kejenuhan dalam program latihan dengan split jump dan shooting.

Latihan shooting dapat meningkatkan tinggi loncatan peserta ekstrakurikuler karena latihan ini merangsang otot untuk selalu berkntraksi dengan cepat baik saat memanjang (eccentric) maupun memendek (concentric) sesuai prinsip gerakan latihan plyometric. Dengan gerakan yang dilakukan berulangulang dan intensitasnya semakin bertambah di setiap pertemuan maka secara tidak langsung dapat meningkatkan power tungkai.

Dalam penelitian ini untuk mengontrol intensitas siswa saat melakukan perlakuan shooting menggunakan denyut jantung. Pengecekan dilakukan untuk mengetahui apakah latihan sudah masuk dalam zona latihan yang ditentukan atau belum. Cara melakukannya yaitu: siswa melakukan perlakuan shooting, setelah selesai peneliti memberi aba-aba mulai untuk menghitung denyut jantung dan berhenti (stop) untuk berhenti menghitung, siswa menghitung dengan cara meraba pembuluh darah yang ada di lehernya, lama menghitung 30 detik dan hasilnya dikalikan dua. Penelitian ini mendukung penelitian terdahulu yang dilakukan oleh Aditya (2016) dengan judul pengaruh latihan shooting terhadap tinggi loncatan siswa peserta ekstrakurikuler bola voli di SMP Negeri 1 Srandakan. Dalam penelitian tersebut ada pengaruh latihan shooting terhadap tinggi loncatan perserta ekstrakurikuler bola voli di SMP N 1 Srandakan.

\section{SIMPULAN}

Berdasarkan analisis hasil penelitian dan pembahasan, dapat disimpulkan bahwa: ada pengaruh latihan shooting terhadap tinggi loncatan perserta ekstrakurikuler bola voli di MA Raudlatul Ulum Anyer, dengan thitung $5.303>t_{\text {tabel }}$ 
2.131. Penelitian ini menghasilkan manfaat bahwa latihan shooting bisa digunakan untuk meningkatkan tinggi loncatan. Di samping itu dengan penelitian ini saran untuk siswa agar bisa lebih aktif dan mengerti bahwa jenis dan bentuk latihan ada bermacam-macam serta hal ini sebagai bahan kajian pelatih untuk memberikan variasi bentuk latihan untuk meningkatkan keterampilan peserta didik.

\section{DAFTAR PUSTAKA}

Rohendi, \& Suwandar, A. (2017). Metode latihan dan pembelajaran bola voli untuk umum. Bandung: Alfabeta.

Ahmadi, N. (2017). Panduan olahraga bola voli. Solo: Era Pustakautama.

Ahmad, S., N. (2011). Pendidikan dan masyarakat. Yogyakarta: Sabda Media.

Arikunto, S. (2012). Prosedur penelitian suatu pendekatan praktek. Jakarta: Rineka Cipta.

Narbuko, C. (2007). Metodologi penelitian. Jakarta: Bumi Aksara.

Djumidar, M. (2004). Belajar berlatih gerak-gerak dasar atletik dalam bermain. Jakarta: Raja Grafindo Persada.

Mumuh, S. (2006). Perbandingan antara siswa yang menjadi pengurus dan bukan pengurus osis dalam pemanfaatan waktu luang dan prestasi belajar di SMK $N 6$ Bandung. Skripsi UPTK UPI Bandung.

Furqon, M., H, \& Doeswes, M. (2002). Pliomtrik untuk meningkatkan power. Program studi ilmu keolahragaan program pascasarjana: Universitas Sebelas Maret Surakarta.

Nasrudin, R. (2010). Pengaruh partisipasi siswa dalam kegiatan ekstrakurikuler terhadap motif berprestasi siswa SMK N 2 Garut. Bandung: Skripsi.

Pertama, I, P. (2013). Pengaruh pelatihan alternate leg bound dan shooting terhadap kelincahan dan daya ledak otot tungkai. Jurnal ilmu keolahragan Undiksha Universitas Udayana, 1(1).

Satriya, Sidik, D., F., \& Imanudin, I. (2014). Modul metodologi kepelatihan olahraga. Bandung: Universitas Pendidikan Indonesia.

Subroto, T., Yunyun, Y., \& Yusuf, H. (2016). Penulisan penelitian tindakan kelas dalam pendidikan jasmani, olahraga dan kesehatan. Bandung: Redpoint.

Subekti, N. (2011). Pengaruh latihan plyometric hurdle hopping dan side double front jump combination terhadap peningkatan power otot tungkai pada pesilat putra UKM Tapak Suci Universitas Supersemar 2011. Solo: Universitas Sebelas Maret Surakarta.

Sukadiyanto. (2010). Pengantar teori dan melatih fisik. Yogyakarta: FIK Universitas Negeri Yogyakarta.

Tilaar, H., A., R. (2012). Pendidikan kebudayaan dan masyarakat madani Indonesia. Bandung: Remaja Rosdakarya. 